\title{
Assessment of Magicland Amusement Park in Abuja as a Flagship Tourist Attraction
}

\author{
Enemuo, O.B ${ }^{1}$, Obijuru, $\mathbf{G}^{2}$ \\ ${ }^{1,2}$ Department of Hotel Management and Tourism, Michael Okpara University of Agriculture \\ Umudike, Abia State, Nigeria
}

\begin{abstract}
The work Assessed of Magic land Amusement Park in Abuja as a Flagship Tourist Attraction. An assessment of the park, highlighting its importance in the recreation industry, could lead to the positioning of Abuja among cities of the world fiercely visited due to the presence of this flag ship attraction. The objectives of the research were to: identify the various amusement parks in Abuja, ascertain the level of patronage by both local and foreign visitors, verify the management principles used in the destination, and suggest management principles that would assume sustainability of the amusement park in the study area. Data for this research was generated using qualitative and quantitative techniques. Simple descriptive technique comprising of mean, standard deviation, and simple frequencies and Likert scale were used to analyze the data. The findings show that development of amusement parks should be carried out in areas closer to the residents, Spacing (Quality of landscape), accessibility, entertainment variety, were seen as factors that were liked least about the parks, while things like safety and security, quality of rides are important, the location of the park, accessibility to the park and the number of thrill rides were seen as attributes that should be improved. Factors like location and attachment, marketing and branding, inept pricing and hidden cost and ignorance of the benefits of recreation and tourism by the residents of Abuja Municipal Area Council led to low patronage of the park, also marketing strategies like the use of fliers, word-of-mouth, brochures etc. were used to increase awareness as well as patronage. Amusement parks help in the attraction of visitors from different countries and Magic land amusement park is not an exception.
\end{abstract}

Keywords: Assessment, Magicland Amusement Park, Flagship, Tourist Attraction.

\section{INTRODUCTION}

Tourism plays an important role in the world economy today. The World Travel Tourism Council (WTTC, 2009) estimates that from direct and indirect activities combined, the Travel and Tourism industry now accounts for 9.9 percent of the global GDP (Gross Domestic Product), 10.9 percent of the total quantity of the world's export and 9.4 percent of the total quantity of the world investment and rising. The economic importance of Travel and Tourism industry cannot be overemphasized. Tourism is a dynamic, evolving consumer driven force and the world's largest industry, if all its interrelated components are placed under one umbrella (Walker, 2007). These components include travel/transportation, hospitality, lodging/accommodation, conventions, expositions, meetings and events, restaurants, managed services, recreation and attractions.

Tourist attractions constitute one of the main goals of a tourist trip. Attractions are the most important elements of a tourist destination, as they provide the main reason or motivation for tourist to visit a destination. According to Kruczet (2006), tourist attractions are "all the components or elements of a tourist product (aspects of the place and event, building and authentic product of higher culture) designated as special ones and possessing the ability to attract tourists, making them choose a given area rather than another, combined with tourist services that create a tourist product". The above definition includes both the nature of the value of a tourist attraction as a special-worthwhile object, distinguished by the addition of a notation and the ability of the attraction to create a tourist product.

Tourists are likely to visit destinations that possess a wide range or variety of interesting facilities and services that they can enjoy. Attractions, according to Swarbrooke (2002), can be divided into four main types: Natural features (beaches, caves, forests),Man-made building, structures and sites that originally designed for a purpose other than attracting visitors (churches, archeological sites), Manmade building, structures and sites that are purpose-built to attract visitors and cater for their needs (Museums, amusement parks) and Special event. 
According to the above division, amusement or theme parks are man-made attractions, built with an aim to attract visitors/tourists and cater for and satisfy their needs. An amusement park (sometimes referred to as a funfair) according to the Collins English dictionary is a group of entertainment attraction, rides and other events in a location for the enjoyment of large numbers of people. Amusement parks have fixed location, as opposed to the travelling funfairs and carnivals and are more elaborate than simple city parks or playgrounds, usually providing attractions meant for all age(Collins English Dictionary).

The Economic Research Association (ERA, 2007) defined amusement parks as "public attractions comprising roller coaster trains and or events belonging to the sphere of entertainment which offers its visitors tickets at fixed prices and which attracts at least 500, 000 visitors annually". The above definition explains an amusement park as a combination of various types of attractions which may be divided into several major categories:- thrill rides, roller coaster rides, family rides, water attractions or rides in darkness in a covered train. (ERA, 2007). Most of the revenue comes from the sale of entrance tickets.

Amusement parks are star players in the tourism industry and play a specific and important role in generating tourism demand (Cleve \&Clark, 2007). Amusement parks all over the world are seen as a flagship attraction because they are considered as tools for economic development and catalyst of urban regeneration, social change and rebranding in urban and rural settings. (Miles, 2005; Plaza, 2008) and they increase local appeal to visitors and quality of life for the residents (Law, 2002).

The Oxford English dictionary (2006) defines flagship as "the best or the most important thing owned or produced by an organization". A major attraction is described as 'flagship' when its appeal is attributed to distinct qualities, including uniqueness, location, international reputation and outstanding media attention, making it a must-see attraction and relatively large in size and economic impact (Law, 2002).

Tourism in Nigeria largely centers on events due to the country's ample amount of ethnic groups, it also includes rain forests, savannah, waterfalls and other natural and man-made attractions. Its capital city, Abuja, is considered to be one of the wealthiest cities in Nigeria. It is fortunate in having plenty of natural attractions. The first amusement park in Abuja and really in the whole of Nigeria, the Magicland Amusement Park and Resort, was opened in $1^{\text {st }}$ March, 2007. (Magiclandng.com) and led to the establishment of other parks in Abuja. The park can be said to be a flagship attraction due to its presence of well-equipped facilities with games and attractive rides including the roller coaster, ocean car etc. and attracts the largest number of fun-loving Abuja resident (Hotels.ng)

The origin of amusement parks lies in ancient and medieval festivals and trade fairs. In the $17^{\text {th }}$ century, large pleasure parks began spreading throughout; these pleasure parks were first permanent public sites dedicated for outdoor entertainment. Attractions included fountains, flower gardens, bowling, games, music, dancing, staged spectacles and a few primitive rides (National Amusement Park Historical Association, NAPHA, 2007). While there were no admission price to enter these gardens, visitors paid for the entertainment and amusement they enjoyed (Wilmeth, 1982). These public entertainment facilities provided the fundamental features that later were featured in commercial parks. The world's oldest operating amusement park is Bakken in Klampenborg, Denmark founded in 1583 (De Groote P. 2009). Towards the end of the $19^{\text {th }}$ century, the offerings of those public gardens changed to a more fast pace, active, thrill oriented amusement parks, as consumers' tastes and preferences changed (Wilmeth, 1982)

At the beginning of the $20^{\text {th }}$ century, there were already hundreds of amusement parks in the whole world. Their development was the result of an increase in peoples' incomes and gradual shortening of the working week. During the $2^{\text {nd }}$ World war, popularity of the traditional amusement parks declined, this attendance drop was due to lack of needed materials during the war, natural disasters, vandalism as well as patron disappointment with the ageing attraction (De Groote P. 2009). In the 70's, there was a considerable renewal of the amusement park industry in the effect of new financial projects. The majority of amusement parks were built in the 70's and today they belong to big globalized amusement park complexes.

Expositions, world fairs or international expositions also impacted the development of the amusement park industry. The emergence of Coney Island, New York as an amusement center is an additional phenomenon relating to the amusement park industry (NAPHA, 2007). Furthermore, technological 
advances, originally featured in world expositions were instrumental to the development of the industry. Nowadays, main attractions are the miracles of science and technology. Amusement parks in its various forms, have been viewed as a central means to fulfill new leisure and tourism trends especially within mature markets, offer more quality for less, they are safe and clean, their offers are multi-optional and time saving, as well as emotional and sense giving and their visitation also meet the needs of soft individualism (Bieger, Dreier and Frey, 2002) and thus the amusement parks have become favored modes of mass entertainment all over the world (Welsh-Heron \& Stevens, 1990; Swarbrooke, 1995; Milman, 2001) of which Abuja is not an exception.

Theme/Amusement parks are important impulses for the leisure and tourism industry and their development (Middleton, 1989; Stevens, 2000; Milman, 2001). For the wealth of an area and its economic development, amusement parks are of utmost importance. Despite the success of some parks, the industry has been fraught with problems. There has not been a rapid growth in the number of amusement parks in Abuja compared to other countries; many parks in Abuja have not been successful from a financial and operative viewpoint.

Amusement parks in Abuja (for example, the Magicland amusement park) has seen a decline since its inception due to developmental and managerial problems and the failure of the Magicland amusement park has damaged the image of the industry and tarnished its reputation as a flagship tourist attraction. There are several factors leading to the failure of the Magicland amusement park in Abuja: Inappropriate location has made the park hard to access, as it is located at the heart of the Abuja City Metropolis, this has created a problem of accessibility as it is or may not be easy for the visitors and residents especially to reach, considering that most residents reside in the suburbs and it takes hours to get to them. This brings to play the problem of poor transportation, as residents are discouraged to move from their initial location to the location of the park;

There is also the problem of poor design and layout with little space or considerable distance between attractions or rides in the park and causes the problem of congestion, during some bad weather conditions the inconveniences are worsened. Poorly trained and unskilled management is another problem affecting the success of the Magicland amusement park. The management and staff are often unqualified or lacked experience in running an amusement park business, also corruption in management also leads to failure of the parks. (Lew, Yu, Ap\& Chang, 2003)

According to Penz and Rosch (2004), the following are factors which led to failure: Unspectacular attractions; Insufficient gastronomy; Poor capacity management; Contrary target market; Bad services and qualities; False pricing; Inappropriate public relations; and Marketing strategies.

Objectives of the study

The general objective of the study is to access the Magicland amusement park in Abuja as a flagship tourist attraction,

Specifically, the study:

1. Identified the amusement parks in Abuja

2. Ascertained the level of patronage by both local and foreign visitor

3. Verified the management principles used in the destination

4. Suggested management principles that would assume sustainability of the amusement park in the study area.

\section{RESEARCH QUESTIONS}

This research will explore the following research questions:-

1. What are the amusement parks available in Abuja?

2. What is the level of patronage of the parks by both local and foreign visitors?

3. What are the management principles used in the destination?

4. What are the management principles that would assume sustainability of the amusement park in the study area? 


\section{MethodologY}

\subsection{Research Design}

The study adopted survey research design.

\subsection{The Area of Study}

The study was carried out in Magicland Amusement park and Resort, Garki, Abuja, the Nigeria's capital, known as the center of excellence. Abuja is located on $8^{\circ} 50^{\mathrm{I}} \mathrm{N}$ and $7^{\circ} 10^{\mathrm{i}} \mathrm{E}$ in Nigeria.

\subsection{Population for the Study}

Abuja Municipal is a local government area known as Area Councils i.e. Abuja Municipal Area Council, and city in Abuja, Nigeria. The towns that make up the area council are: Karu, Nyanya, Durumi, Garki, Ketti, Kabusa, Mabushi, Jabi, Lugbe, IdoToge, Hulumi, Pyakasa, Jikwoyi, Kurudu, Orozo, Maitama, Karshi, Gwagwa, Karmo, Sheretti and Asokoro. The population of the study is 776,298 people according to the 2006 National Population Census for Abuja Municipal Area Council.

\subsection{Sample/Sampling Techniques}

The purposive and accessibility sampling techniques were used to determine the sample for the study.

\subsection{Data Collection Techniques}

The researcher administers by hand through a representative 400 questionnaires to the residents of AMAC, visitors present in the park at the time visited, which was filled and returned at the spot by the respondents. An open ended oral interview was carried out on the spot with the park management; Key informant interview was conducted using the interview schedule. Questionnaires were issued to visitors and park management on a ratio of 400:1

\subsection{Data Analysis Technique}

Simple descriptive technique was used to analyze the objectives; Simple descriptive technique uses such measures as mean, median, mode, variance, deviation, percentages and correlation. Simple percentages were used to analyze objective one: to identify the various amusement parks in the Abuja, simple percentages and the use of likert scale was used to analyze objective two: which ascertains the level of patronage by both local and foreign visitors, simple percentages was used for objective three: which verifies the management principles used in the destination or attraction; and likert scale were used to analyze objective four: which suggests management principle that would assume sustainability in the attraction.

\section{Data Presentation}

\section{Research Question 1: What are the amusement parks in Abuja?}

Table1. Identifies parks in the study area

\begin{tabular}{|l|}
\hline Parks \\
\hline Magicland Amusement park \\
Maitama Amusement park \\
\hline
\end{tabular}

Attractions in the Identified Parks

The attractions available in the Magicland amusement park include: Flying tower, Pirate ship, Fire fighter, Fulani hut, Ferris wheel, KongaKrazy bouncing castle, the big worm, Water splash, the fun arcade, Waka about bridge, Bamba shop, Shisha hut.

Attractions available in the Maitama amusement park include Strong man, Video arcade, food court, roller skating, perimeter trains, merry-go-rounds, slides and bumper boats.

The Magicland amusement park is the first and most equipped amusement park hence its choice as the study area.

\section{Attractions in the Magicland Amusement Park, Abuja}

\subsection{Restaurant}

The amusement park has a restaurant called the Fulani ranch. The Fulani ranch provides continental Mediterranean and African cuisines. 


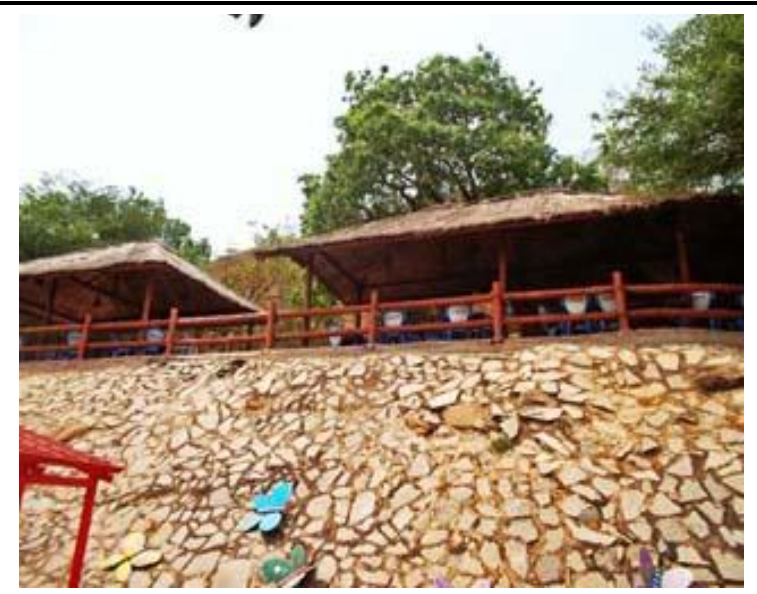

Plate1. Fulani hut

\subsection{Cafeterias and Shops}

There are cafeterias and shops all over the place for visitors' satisfaction. The cafes includes the forest café and the Shisha hut, each offering foods with unique and delicious tastes Some of the shops include the wonder shop, Nina candy shop, fountain shop, Bamba shop and many others

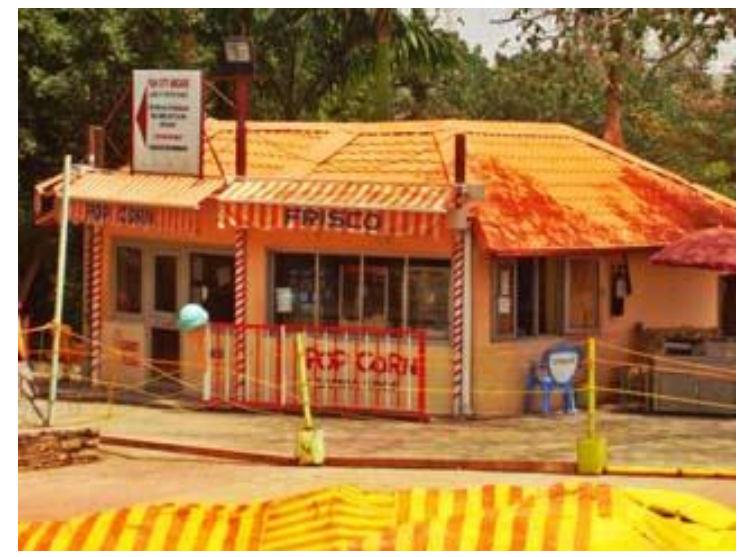

Plate2. Bamba Shop

One of the many relaxation spots in the Magicland is the fountain square, with a beautiful view. The Magicland also has an elaborate arcade building called the Fun city Arcade.

\subsection{Fun City Arcade}

The fun arcade is elaborately equipped with variety of indoor games, some of which include the 'Bull fight', Bumper boat. Basketball, and video games for all ages. The arcade has space for conferences and annual general meetings. The available food and drink booths within the arcade makes it easy for visitors to take a break and have something to eat or drink. There is always something to satisfy the customers at very friendly prices. The collection of arcade games include; Rodeo bull game, jungle land, Ghost squad, crazy hops (Basketball), Battle gear 3, space jungle, Hippo park, Diddan paradise and many more. There is also the arcade restaurant.

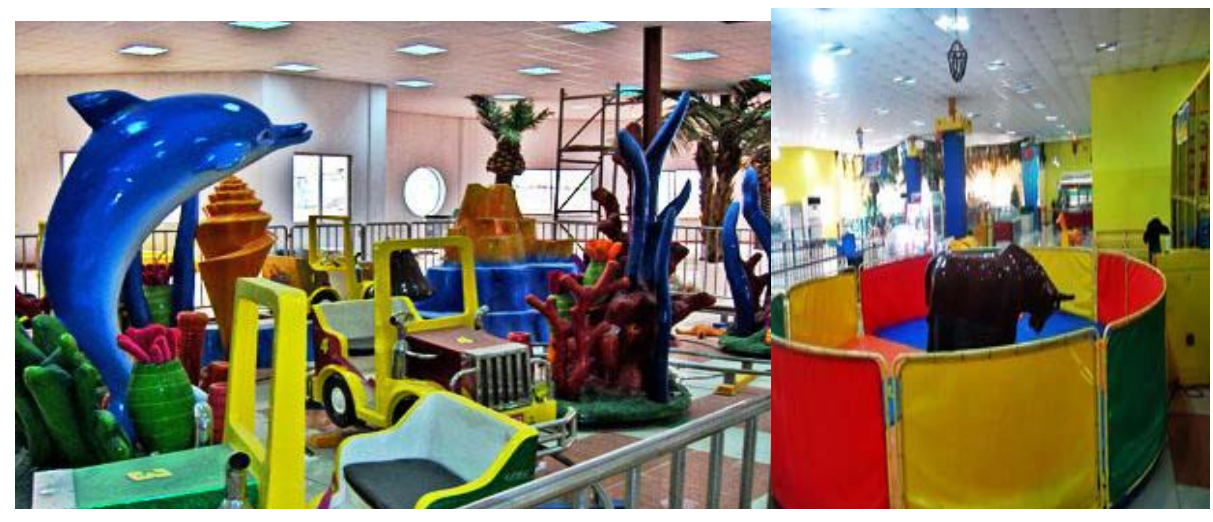



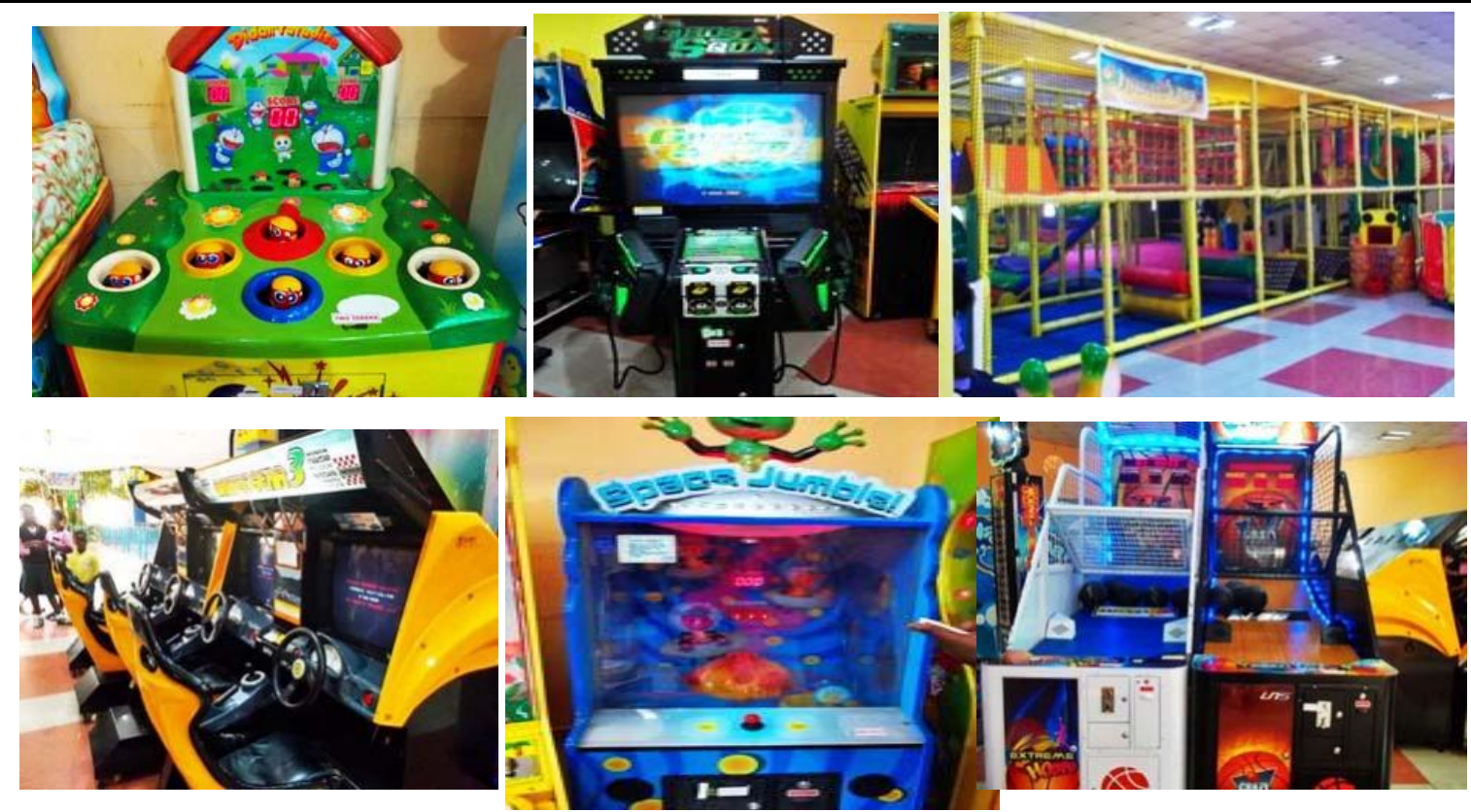

Plate3. The Fun Arcade

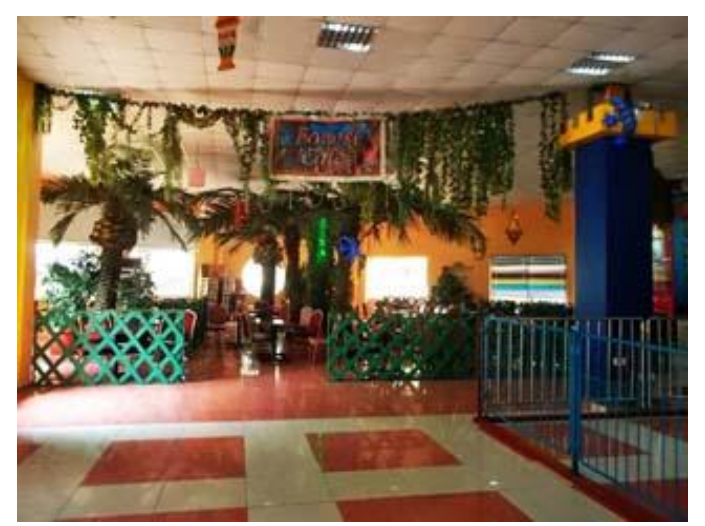

Plate4. The Arcade Restaurant

\subsection{Rides}

There are also a number of rides for all ages to provide maximum fun.

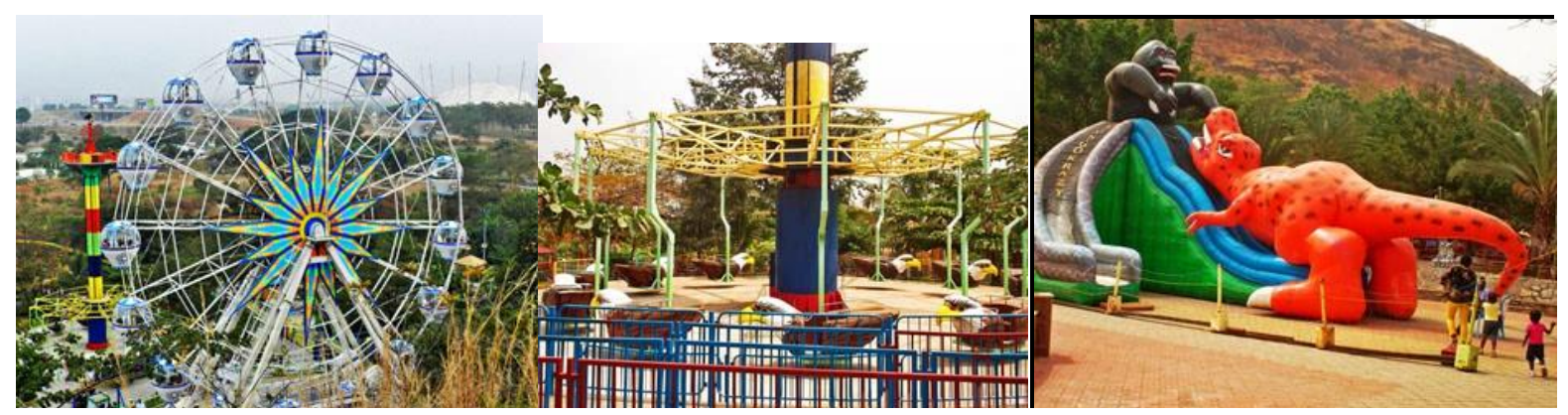

Ferris wheel

Flying tower

KongoKrazy bouncing castle

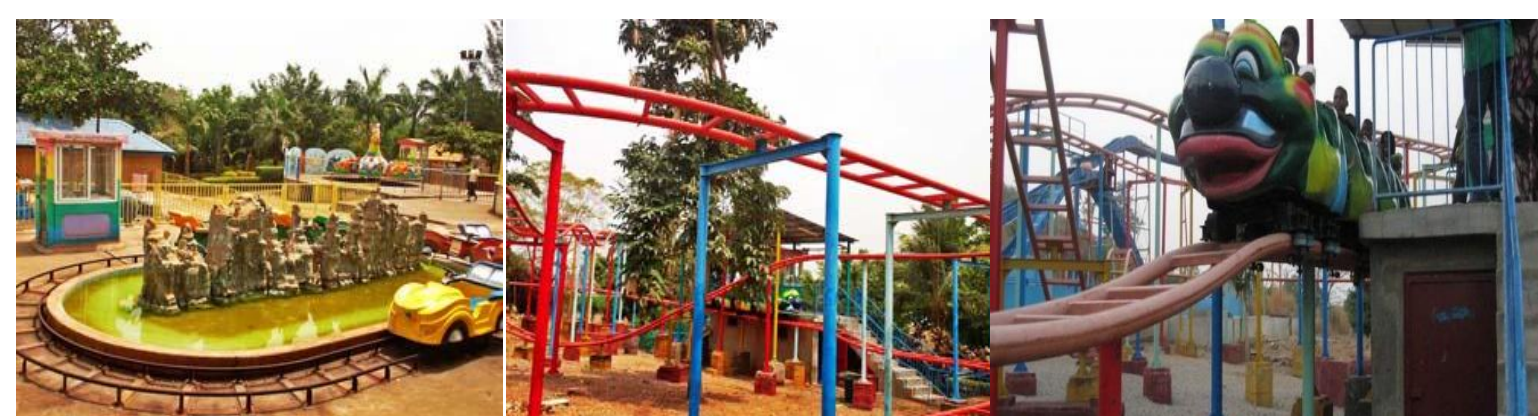

The Fire Fighter

The Big Worm 


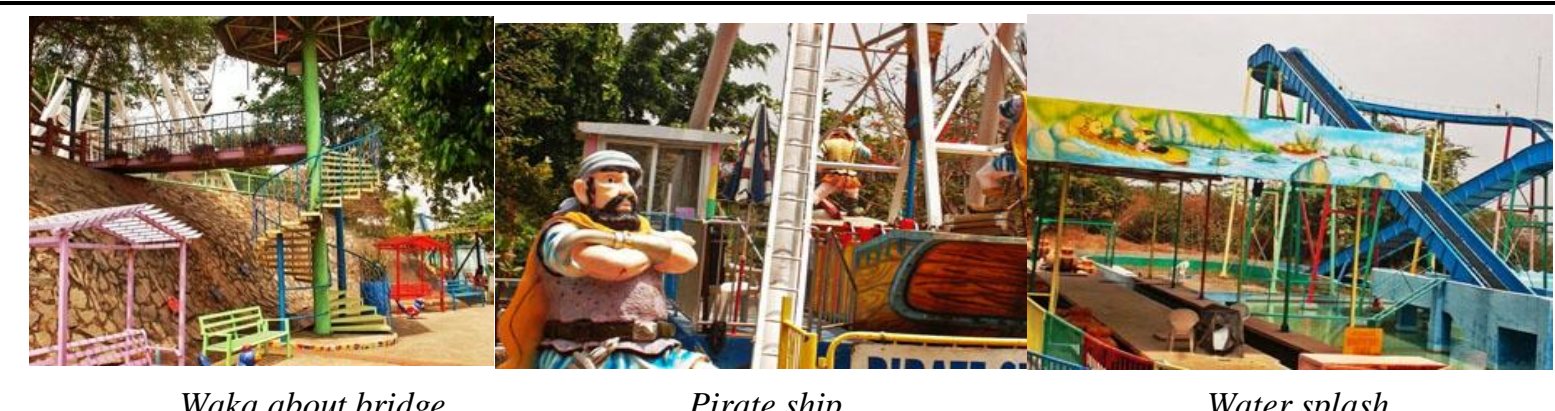

Waka about bridge

Pirate ship

Water splash

Plate5. The various rides in the amusement park

Table2. Perception of the Attractiveness of the Park by the Respondents

\begin{tabular}{|l|l|l|}
\hline & Frequency & Percentage \\
\hline Extremely attractive & 259 & 65 \\
\hline Very attractive & 111 & 28 \\
\hline Slightly attractive & 30 & 7 \\
\hline Very unattractive & - & - \\
\hline Total & 400 & 100 \\
\hline
\end{tabular}

From Table 2 above, $65 \%$ of the respondents said the park was extremely attractive, $28 \%$ of the respondents said that the park was very attractive, while $7 \%$ of the respondents said the park was slightly attractive.

\section{Research Question 2: What is the level of patronage/attendance?}

Table3. Means of accessibility to the park

\begin{tabular}{|l|l|l|}
\hline & Frequency & Percentage \\
\hline Personal car & 80 & 20 \\
\hline Public transportation & 300 & 75 \\
\hline Walking & 20 & 5 \\
\hline Total & 400 & 100 \\
\hline
\end{tabular}

From table 3 above, $20 \%$ of the respondents came by private car, $75 \%$ of the respondents came by public transport while $5 \%$ of the respondents walked to the park from their places of residence.

Table4. Part of the city the respondents visited from

\begin{tabular}{|l|l|l|}
\hline & Frequency & Percentage \\
\hline Abuja municipal area council & 347 & 87 \\
\hline Abaji area council & 10 & 2 \\
\hline Gwagwalada area council & 15 & 4 \\
\hline Kuje area council & 20 & 5 \\
\hline Bwari area council & 8 & 2 \\
\hline Kwali area council & 5 & 1 \\
\hline Total & 400 & 100 \\
\hline
\end{tabular}

From table 4 above, $87 \%$ of the respondents of the respondents came from AMAC, $2 \%$ of the respondents came from Abaji area council, $4 \%$ of the respondents came from Gwagwalada area council, $5 \%$ of the respondents came from Kuje area council, $2 \%$ of the respondents came from Bwari area Council, and $1 \%$ of the respondents came from Kwali area council.

Table5. General cost of visiting the amusement park in terms of both gate fee and ride tariff

\begin{tabular}{|l|l|l|}
\hline Details & Frequency & Percentage \\
\hline Very high & - & - \\
\hline High & 10 & 2 \\
\hline Moderate & 390 & 98 \\
\hline Low & - & - \\
\hline Total & 400 & 100 \\
\hline
\end{tabular}

From table 5 above, $0 \%$ of the respondents indicated that the cost of visiting the park is very high, $2 \%$ of the respondents said that the general cost of visiting the amusement park is high, while $98 \%$ of the respondents said that cost of visiting the park is moderate. 
Enemuo, O.B \& Obijuru, G

Table6. Attributes that are liked the most and liked least about the Magicland Amusement park. The attributes are classified into seven (7) categories/factors or key words.

\begin{tabular}{|l|l|l|l|}
\hline Attributes/Characteristics & Liked most (\%) & Liked least (\%) & Undecided (\%) \\
\hline $\begin{array}{l}\text { Factor 1: Food variety and } \\
\text { value for money }\end{array}$ & 65 & 22 & 12 \\
\hline $\begin{array}{l}\text { Factor 2: Accessibility to the } \\
\text { park }\end{array}$ & 83 & 100 & 17 \\
\hline Location of the park & 13 & 75 & 12 \\
\hline Ease of access & 70 & 25 & 5 \\
\hline $\begin{array}{l}\text { Factor 3: Quality of } \\
\text { landscaping and design }\end{array}$ & 149 & 299 & 52 \\
\hline Spacing between attractions & 3 & 92 & 5 \\
\hline Layout of the park & 70 & 20 & 10 \\
\hline Creativity exhibited in the park & 53 & 45 & 2 \\
\hline Too crowded & 3 & 75 & 22 \\
\hline Long queuing time & 20 & 67 & 13 \\
\hline Factor 4: Courteous and safe & 197 & 18 & 40 \\
\hline $\begin{array}{l}\text { Quality of management and } \\
\text { staff }\end{array}$ & 70 & 10 & 20 \\
\hline Ride safety & 72 & 8 & 20 \\
\hline $\begin{array}{l}\text { Factor 5: Pricing and value for } \\
\text { money }\end{array}$ & 55 & 85 & 10 \\
\hline $\begin{array}{l}\text { Factor 6: Quality and variety } \\
\text { of rides and attraction }\end{array}$ & 103 & 68 & 19 \\
\hline Quality of rides and attraction & 80 & 8 & 12 \\
\hline $\begin{array}{l}\text { Overall number of attractions } \\
\text { in the park }\end{array}$ & 23 & 60 & 17 \\
\hline $\begin{array}{l}\text { Factor 7: Entertainment } \\
\text { variety and quality }\end{array}$ & 92 & 161 & 23 \\
\hline $\begin{array}{l}\text { Number of entertainment } \\
\text { options }\end{array}$ & 25 & 56 & 19 \\
\hline $\begin{array}{l}\text { Variety of entertainment } \\
\text { options }\end{array}$ & 15 & 25 & 12 \\
\hline $\begin{array}{l}\text { Quality of family oriented } \\
\text { activities }\end{array}$ & 52 & 80 & \\
\hline
\end{tabular}

From table .6 above, $65 \%$ of the respondents liked food variety the most, $22 \%$ of the respondents liked it the least while $12 \%$ of the respondents were undecided, $83 \%$ of the respondents liked accessibility to the park the most, $100 \%$ of the respondents liked it the least while $17 \%$ of the respondents were undecided, on quality of landscaping and design, $149 \%$ of the respondents liked it the most, $299 \%$ of the respondents liked it the least while $52 \%$ of the respondents were undecided. On courteous and safety, $197 \%$ of the respondents liked it the most, $18 \%$ of the respondents liked it the least while $40 \%$ of the respondents were undecided. On pricing and value for money, $55 \%$ of the respondents liked it the most, $35 \%$ of the respondents liked it the least while $10 \%$ of the respondents were undecided. On quality and variety of rides and attraction, $103 \%$ of the respondents liked it the most, $68 \%$ of the respondents liked it the least while $19 \%$ of the respondents were undecided. On entertainment variety and quality, $90 \%$ of the respondents liked it the most, $101 \%$ of the respondents liked it the least while $47 \%$ of the respondents were undecided.

Table7. Attributes or characteristics of importance for visiting the park by respondents

\begin{tabular}{|l|l|l|}
\hline Attributes or characteristics & $\Sigma$ & $\overline{\mathrm{x}}$ \\
\hline Safety/security & 1480 & 3.7 \\
\hline Convenience of public transport & 1180 & 2.9 \\
\hline Friendly and courteous staff & 1310 & 3.2 \\
\hline Creativity exhibited in the park & 1260 & 3.1 \\
\hline Quality of landscaping & 1460 & 3.6 \\
\hline Cleanliness of the park & 1510 & 3.8 \\
\hline Overall quality of the accessibility of the park & 1051 & 2.6 \\
\hline Layout of the park & 1435 & 3.6 \\
\hline Number of entertainment variety \& quality & 1540 & 3.8 \\
\hline
\end{tabular}


Assessment of Magicland Amusement Park in Abuja as a Flagship Tourist Attraction

\begin{tabular}{|l|l|l|}
\hline \hline Quality of rides & 1422 & 3.5 \\
\hline Overall perceived value for money & 1408 & 3.5 \\
\hline Staff knowledge about the park features & 1360 & 3.5 \\
\hline Overall number of attraction in the park & 1500 & 3.7 \\
\hline Price of admission & 1860 & 4.6 \\
\hline Number of thrill rides & 1038 & 2.6 \\
\hline Rides or activities that appeal to the people of all ages & 1780 & 4.4 \\
\hline Rides or activities that appeal to families & 1784 & 4.5 \\
\hline Variety of food prices & 1720 & 4.3 \\
\hline
\end{tabular}

From table 7 above, and acting on the decision rule, the respondents agreed that factors like Safety/security, Friendly and courteous staff, Creativity exhibited in the park, Quality of landscaping, Cleanliness of the park, Layout of the park, Number of entertainment variety \& quality, Quality of rides, Overall perceived value for money, Staff knowledge about the park features, Overall number of attraction in the park, Price of admission, Rides or activities that appeal to the people of all ages, Rides or activities that appeal to families, Variety of food prices were enough to pull them to visit the park. While the respondents disagreed that factors like convenience of public transport, overall quality of accessibility to the park, and number of thrill rides were factors that would make them want to visit,

Where $\Sigma=$ the summation of all the frequencies (refer to appendix II)

$$
\mathrm{X}=\text { the mean values }
$$

Decision Rule: Any item with mean response of $\geq 3.0$ was regarded as agreed. This indicated that respondents agreed. If any item with a mean response of $\leq 3.0$, was regarded as disagreed, this means that the respondents disagreed.

\section{Research Question 3: What are the management principles used in the park?}

Table8. Management principle used in the park

\begin{tabular}{|c|c|c|c|}
\hline Principles & Yes\% & No\% & Undecided\% \\
\hline Division of labor & 57 & - & 43 \\
\hline Discipline & 55 & - & 45 \\
\hline Unity of direction (same vision and objectives) & 65 & 5 & 33 \\
\hline Subordination of individual's interest for general interest & 25 & 5 & 70 \\
\hline Remuneration (payment of staff at appropriate time) & 45 & - & 55 \\
\hline Centralization and decentralization & 47 & - & 53 \\
\hline Scalar chain (Line of authority from highest to lowest) & 25 & 3 & 72 \\
\hline Order (Placing the right person on the right job) & 52 & 3 & 45 \\
\hline Equity (Treating subordinates in just and kind manner) & 73 & - & 27 \\
\hline Stability of tenure of personnel (Low staff turnover) & 50 & 3 & 47 \\
\hline Initiative (Working while expressing one's thought) & 5 & 45 & 50 \\
\hline Team spirit (The use of 'we' instead of 'I' in a conversation & 53 & 2 & 45 \\
\hline
\end{tabular}

From table 8 above, for Division of labor, $57 \%$ of the respondents said yes, none of the respondents said no and $43 \%$ of the respondents were undecided, for Discipline, 55\% of the respondents said yes, none of the respondents said no and $45 \%$ of the respondents were undecided, for Unity of direction (same vision and objectives), $67 \%$ of the respondents said yes, $5 \%$ of the respondents said no and $33 \%$ of the respondents were undecided, for Subordination of individual's interest for general interest, $25 \%$ of the respondents said yes, $5 \%$ of the respondents said no and $70 \%$ of the respondents were undecided, for Remuneration (payment of staff at appropriate time), $45 \%$ of the respondents said yes, none of the respondents said no and 55\% of the respondents were undecided, for Centralization and Decentralization, $47 \%$ of the respondents said yes, none of the respondents said no and $53 \%$ of the respondents were undecided, for Scalar chain (Line of authority from highest to lowest), 25\% of the respondents said yes, $3 \%$ of the respondents said no and $72 \%$ of the respondents were undecided, for Order (Placing the right person on the right job), 52\% of the respondents said yes, $3 \%$ of the respondents said no and $45 \%$ of the respondents were undecided, for Equity (Treating subordinates in just and kind manner), $73 \%$ of the respondents said yes, none of the respondents said no and $27 \%$ of the respondents were undecided, for Stability of tenure of personnel (Low staff turnover), $50 \%$ of the respondents said yes, $3 \%$ of the respondents said no and $47 \%$ of the respondents were undecided, for 
Initiative (Working while expressing one's thought), $5 \%$ of the respondents said yes, $45 \%$ of the respondents said no and 50\% of the respondents were undecided, while for Team spirit (The use of 'we' instead of 'I' in a conversation), 53\% of the respondents said yes, $2 \%$ of the respondents said no and $45 \%$ of the respondents were undecided. Therefore based on the affirmative answers, the Division of labor, 57\%, Discipline 55\%, Unity of direction 67\%, Order 52\%, Equity 73\%, Stability of tenure of personnel 50\%, and Team spirit 53\% these management principles were seen as mostly used in the Magicland amusement park.

\section{Research Question 4: What are the management principles that would assume sustainability of the park?}

Table9. Management principles that will ensure sustainability

\begin{tabular}{|l|l|l|}
\hline Management principles & $\Sigma$ & $\overline{\mathbf{x}}$ \\
\hline Division of labor & 2000 & 5 \\
\hline Authority (The right to give order and the power to exact obedience) & 1720 & 4.3 \\
\hline Discipline & 2000 & 5 \\
\hline Unity of command (receiving orders from one manager) & 1890 & 4.7 \\
\hline Unity of direction (same vision and objectives) & 1970 & 4.9 \\
\hline Subordination of individual's interest for general interest & 1890 & 4.7 \\
\hline Remuneration (payment of staff at appropriate time) & 2000 & 5 \\
\hline Centralization and decentralization & 1920 & 4.8 \\
\hline Scalar chain (Line of authority from highest to lowest) & 1720 & 4.3 \\
\hline Order (Placing the right person on the right job) & 2000 & 5 \\
\hline Equity (Treating subordinates in just and kind manner) & 2000 & 5 \\
\hline Stability of tenure of personnel (Low staff turnover) & 1980 & 4.9 \\
\hline Initiative (Working while expressing one's thought) & 1720 & 4.3 \\
\hline Team spirit (The use of 'we' instead of 'I' in a conversation & 2000 & 5 \\
\hline Creativity & 2000 & 5 \\
\hline Statement of purpose and mission & 1720 & 4.3 \\
\hline
\end{tabular}

From Table 9 above, and in observance of the decision rule, the respondents agreed that Division of labor, with mean response of 5, Authority, with mean response of 4.3,Discipline, with mean response of 5, Unity of command, with mean response of 4.7,Unity of direction, with mean response of 4.9, Subordination of individual's interest for general interest, with mean response of 4.7, Remuneration, with mean response of 5, Centralization and Decentralization, with mean response of 4.8 , Scalar chain, with mean response of 4.3 , Order, with mean response of 5, Equity, with mean response of 5, Stability of tenure of personnel, with mean response of 4.9, Initiative, with mean response of 4.3, Team spirit, with mean response of 5, Creativity, with mean response of 5 and Statement of purpose and mission, with mean response of 4.3 were management principles that will ensure sustainability.

Decision Rule: Any item with mean response of $\geq 3.0$ was regarded as agreed. This indicated that respondents agreed. If any item with a mean response of $\leq 3.0$, was regarded as disagreed, this means that the respondents disagreed.

Table10. Reasons for low patronage to the Magicland amusement parks

\begin{tabular}{|l|l|l|}
\hline Reasons for low patronage & $\boldsymbol{\Sigma}$ & $\mathbf{\mathbf { x }}$ \\
\hline Failing customers' expectation & 1340 & 3.4 \\
\hline Improper marketing and branding & 1510 & 3.8 \\
\hline Failed location and attachment & 1350 & 3.4 \\
\hline Inept pricing and hidden cost & 1450 & 3.6 \\
\hline Negative innovation and investment capital & 880 & 2.2 \\
\hline Lacking entrepreneurship and technical know-how & 920 & 2.3 \\
\hline Poor human resource management & 825 & 2.1 \\
\hline Bad service attitude & 762 & 1.9 \\
\hline Ignorance of the essence of the benefits of relaxation and tourism & 1740 & 4.35 \\
\hline
\end{tabular}

From Table 10 above, the respondents agreed that Failing customers' expectation, improper marketing and branding, failed location, inept pricing and hidden cost, and ignorance of the essence of the benefits of relaxation and tourism as the reasons for low patronage, while the respondents disagreed that factors like negative innovation and investment capital, Lacking entrepreneurship and technical know-how, poor human resources and bad service attitude were reasons for failure/low patronage. 
Decision Rule: Any item with mean response of $\geq 3.0$ was regarded as agreed. This indicated that respondents agreed. If any item with a mean response of $\leq 3.0$, was regarded as disagreed, this means that the respondents disagreed.

\section{Open Ended InTERVIEW With The AMUSEMEnt PARK MANAgement}

To verify or discard findings in objective three and four the following open ended questions were asked to the Magicland amusement park management at the end: The figurative level of patronage; Factors that lead to low patronage; Management principles applied. Also Challenges encountered during development and management and Marketing strategies to be used to increase patronage were asked.

1. The figurative level of patronage: Above 300, 000 per annum

2. Factors that lead to low patronage: Improper marketing, inept pricing and ignorance of the benefits of relaxation and tourism by the Abuja residents.

3. Management principles that apply in the amusement park: Division of labor, Authority, Discipline, Unity of command, Unity of direction, Subordination of individual's interest for general interest, Remuneration, Centralization and decentralization, Scalar chain, Order, Equity, Stability of tenure of personnel, Initiative, Team spirit, Creativity and Statement of purpose and mission

4. Challenges encountered during development and in management of the amusement park: Costly infrastructure, Maintenance of rides and attractions, Staff management in terms of remuneration, Low returns on Investments and most importantly lack of electricity

5. Marketing strategies used to increase awareness as well as patronage: Use of fliers, word-ofmouth, brochures (which will be placed strategically at embassies, schools, and airports) and giving special offers to visitors

\section{MAJOR FINDINGS}

Based on the objectives of the study, literature review and analysis of data, the following findings deemed appropriate:

1. The amusement park was inaccessible to those living further away from the city center making it difficult for them to visit on a regular basis and the cost of transporting themselves had reduced their interest for regular visits.

2. General cost of visiting the amusement park is moderate.

3. Spacing (Quality of landscape), accessibility, entertainment variety, were seen as factors that were liked least about the parks

4. While things like safety and security, quality of rides are important, the location of the park, accessibility to the park and the number of thrill rides were seen as attributes that should be improved.

5. Factors like location and attachment, marketing and branding, inept pricing and hidden cost and ignorance of the benefits of recreation and tourism by the residents of Abuja Municipal Area Council led to low patronage of the park

6. Amusement parks help in the attraction of visitors from different countries and Magicland amusement park is not an exception.

7. Application of the management principle led to the development of the park

8. Marketing strategies like use of fliers, word of mouth, brochures and giving special offers to visitors were used to increase awareness as well as patronage.

\section{DISCUSSION OF FINDINGS}

Table 1 revealed that the Magicland Amusement park is the most visited park in the Abuja Municipal Area Council (AMAC).

Table 2 revealed that the Magicland amusement park was extremely attractive and therefore it is termed a flagship attraction, because it is to be understood to be the "best and the most important attraction" as was explained by Weidenfeld A, (2010) and is associated with such features as the 
exceptional nature of the place, the international importance, considerable size and significant economic benefits.

Table 3 revealed that a greater number of the respondents came to the park by public transportation, which according to the problem statement makes the amusement park difficult to access by residents living afar and brings to play the problem of transportation. Xiaoxi Deng (2011), stated in his research that 'the location of parks can cause a major problem of accessibility as public transport was limited and travel time from residents location to the amusement park takes at least two hours or more".

Table 4 revealed that the greater percentage of the respondents visited from around the area where the amusement park was situated, this poses as a major problem to the development and level of patronage to the amusement park, as only a few residents visit while the bulk of the residents find it difficult to visit, this is in line with the findings of Deng (2011), whose respondents perceived that convenience to the public and accessibility were important attributes for evaluating a theme/ amusement park.

Table 5 revealed that the respondents saw the cost of visiting the Magicland amusement park in terms of both the gate fee and ride tariff as moderate. Peter Dybedal (1998) stated in his research that " the survival of attractions for the local area will necessarily be influenced by the financial viability, therefore as much as amusement parks intend to get back its Returns on Investment, costs should also be favorable to visitors'

Findings in Table 6 revealed that what the respondents like least about the Magicland amusement park was mainly the level of accessibility to the park and the quality of landscaping and design, this was explained in the work of Pikkemaat and Schuckert (2007), they stated that "a wrong location implies the missing catchment area as well as under-developed or missing transport connection and infrastructure". The respondents also perceived that the value for money, courteous staff and safe rides, variety of attractions and food variety and value for money were attributes the liked most about the Magicland amusement park.

Table 7 revealed that the respondents perceived that convenience of public transportation, overall quality of accessibility to the park and number of thrill rides were attributes that hamper repeated visit to the park, while the value for money for food purchases, variety of food prices, quality of food and rides and activity that appeals to families although less important attributes, seems to be the factors that pulls them to repeated visits. It seems that while the cost of the experience is moderate, the opportunity to have a memorable experience is of higher priority and a more memorable experience through improved thrill rides will result in greater willingness to pay among park visitors, thereby increasing the level of patronage, Deng (2011)

Table 8 revealed that the respondents perceived that Division of labor, Discipline, Unity of direction, Order, Equity, Stability of tenure of personnel, and Team spirit, were management principles that the feel was applied in the management of the park.

Table 9 revealed that the respondents perceived that division of labor, authority, discipline, unity of command, unity of direction, subordination of individual's interest for general interest, remuneration, centralization and decentralization, scalar chain, order, equity, stability of tenure of personnel, initiative, team spirit, creativity and statement of purpose and mission as the management principles that would ensure sustainability of the Magicland Amusement park. These management principles, according to Henri Fayol (1916), are ingredients for successful management and that they explain how managers should organize and interact with staff in a productive way. He stressed that although they are seen as common sense, they are revolutionary concepts for organizational management.

Table 10 revealed that the respondents saw Failing customers' expectation, improper marketing and branding, failed location, inept pricing and hidden cost, and ignorance of the essence of the benefits of relaxation and tourism were the reasons for low patronage, while negative innovation and investment capital, Lacking entrepreneurship and technical know-how, poor human resources and bad service attitude were not the reasons for failure. This was highlighted in the work of Pikkemaat and Schuckert (2007), that low patronage occurs when "the product delivered gaps and description of the product, they miss authenticity, credibility experience and adventure and therefore the customers gets bored, misses a certain wow factor and the park lacks of repetitive visits" 
On the open ended questions asked to the management of the park, the result gotten revealed that the park records above 300, 000 visitors both national and foreign, the management stressed the fact that improper marketing, inept pricing and ignorance of the benefits of relaxation and tourism by the Abuja residents were reasons for low patronage. The management agreed that all these management principles (Division of labor, Authority, Discipline, Unity of command, Unity of direction, Subordination of individual's interest for general interest, Remuneration, Centralization and decentralization, Scalar chain, Order, Equity, Stability of tenure of personnel, Initiative, Team spirit, Creativity and Statement of purpose and mission) were being not just applied but practiced by the amusement park managers.

On the challenges encountered during the development and in the management of the amusement park, Costly infrastructure, Maintenance of rides and attractions, Staff management in terms of remuneration, Low returns on Investments and most importantly lack of electricity were mentioned.

The management stated that the use of fliers, word-of-mouth, brochures (which will be placed strategically at embassies, schools, and airports) and giving special offers to visitors were marketing strategies in place to increase the awareness of the flagshipness of the amusement park thereby increasing patronage. Despite standardization, the success of the amusement park project sometimes depends on variety. This forces management of parks to having to continually monitor attendance as well as to an analysis of visitors needs by resorting to various marketing tools (Kruczek Z, 2006).

\section{Conclusion}

Tourist attraction constitute one of the main goals of a tourist trip, as attractions are the most important element of a tourist destination, as they provide the main reason or motivation for tourist to visit a destination. Amusement park -being the man-made attraction built with the aim of attracting visitors/tourist- should be looked upon to ensure effective planning that would help in satisfying the tourists' need for fun and relaxation. Stakeholders should understand that amusement parks, although not projects that can be developed in a short period of time, should be planned and built in rural areas, accessible to the majority of the population and should be developed in such a way that it will attract the visitors/tourist, here creativity is of importance, building of thrill rides and attractions that adds the 'wow' effect and ensures repetitive visits. The managers should also ensure that they are practicing the various management principles so as to ensure sustainability of the amusement park. Marketing and branding is of utmost importance if the residents and indeed the world at large is to appreciate the presence of a flagship attraction in Abuja and if the benefits of relaxation and tourism is somehow imbibed into the consciousness of the residents half of the problem would have been solved. Therefore, to ensure that the amusement park becomes a flagship attraction, "its appeal has to be attributed to distinct qualities, including uniqueness, location, international reputation and outstanding media attention, making it a 'must-see' attraction and relatively large in size and economic impact" (Law, 2002).

\section{RECOMMENDATIONS}

From the findings above, the following were recommended:

$>$ The amusement parks are built in areas that would be accessible to those living further away from the city center in other to increase their interest for regular visits.

$>$ Although the general cost of visiting the amusement park is moderate, it could still be reduced to ensure that the visitors engage in as much rides as possible to ensure maximum satisfaction.

$>$ The developers and stakeholders should ensure that Spacing (Quality of landscape), accessibility, entertainment variety are resolved to prevent congestion and reduced patronage

$>$ While things like safety and security, quality of rides are important, the location of the park, accessibility to the park and the number of thrill rides are factors that should not be overlooked during planning and development of the amusement parks.

$>$ To reduce low patronage, factors like location and attachment, marketing and branding, inept pricing and hidden cost and ignorance of the benefits of recreation and tourism by the residents of Abuja Municipal Area Council should be worked upon.

$>$ Application of the management principle led to the development of the amusement park and it will also ensure sustainability if effectively carried out.

$>$ Efforts should be put into marketing and branding of the park, to showcase its attractiveness as a flagship attraction, this will put the Magicland amusement park into cognizance of the international community thereby attracting foreign visitors. 


\section{REFERENCES}

[1] Bieger, T., Dreir P. \& Frey, M. (2002) Anforderunfen an Attraktionspunkteiminternationalen Sight-Seeing Tourisimus - Result ateeiner explorativen Delphi-studie. St. Gallen: Universit at St. Gallen, Unpublished

[2] Cleve, S. A. (2007). The Global Theme Park Industry. Cambridge MA: CAB International.

[3] De Groote P. (2009) Globalization of Commercial Theme Parks Case: The Walt Disney Company [in:] $4^{\text {th }}$ Aspects and Visions of Applied Economics and Informatics. Debrecen

[4] Kruczek,K.(2006).Attraktivitycestovnehoruchuakopredmetinterdisciplinarnehovyskumu, "Cestno vnyruchakointerdisciplinarny jai a jei a jehovyskum”, Acta Oeconomica No.19, Bariska Bystrzyca, p. 115-123, ISSN 80-8083-211-0

[5] Law, C. M. (2002) Urban Tourism: The Visitor Economy \& the Growth of large cities (2 ${ }^{\text {nd }}$ Ed.)London: Continuum

[6] Lew, A.A., Yu, L., Ap, J., \& Zhang, G. (2003) Tourism in China. Binghamton NY: The Haworth Hospitality Press.

[7] Miles, S. (2005). 'Our Tyne': Iconicity Regeneration and the Revitalization ofIdentity in Newcastle Gates head. Urban Studies, 42 (5-6), 913-926

[8] Milman, A. (2001). The Future of Theme Parks and Attraction Industry: A Management Perspective. Journal of Travel Research, 40 (November), 139-147

[9] National Amusement Park Historical Association (2007) Retrieved on 01/02/2007from http://napha. org/nnn/Default.aspx?tabid=69

[10] Oxford English Dictionary (2006) Concise Oxford English dictionary. Oxford, UK: Oxford University Press

[11] Plaza, B. (2008) on some Challenges and Conditions for the Guggenheim Museum Bilboa to bean Effective Economic re-activator. International Journal of Urban and Regional Research, 32 (2), 506-517.

[12] Swarbrooke, J. (1995): The Development and Management of Visitor Attractions. Oxford: Butterworth-Heinemann.

[13] Walker, J. R (2007) Introduction to Hospitality Management $2^{\text {nd }}$ edition. NewJersey: PrenticeHall.

[14] Wilmeth, D. B. (1982) Variety Entertainment and Outdoor Amusement. Westport, C.T.Greenwood Press

[15] WTTC, WTO, Earth Council (1996) Agenda 21 for the Travel and Tourism Industry; Toward Environmentally Sustainable Development. International Hotel Group Ltd, London, UK. 